\title{
KELIMPAHAN LARVA IKAN BERDASARKAN FASE BULAN DI PADANG LAMUN PANTAI PRAWEAN, JEPARA
}

\author{
Abundance of Fish Larvae Based on Moon Phase in Prawean Beach Seagrass, Jepara.
}

\author{
Fitriana Hidayaturrohmah, Bambang Sulardiono*), Wiwiet Teguh Taufani
}

Program Studi Manajemen Sumberdaya Perairan, Departemen Sumberdaya Akuatik Fakultas Perikanan dan Ilmu Kelautan Universitas Diponegoro Jl. Prof. Soedarto, SH, Tembalang, Semarang, Jawa Tengah - 50275, Telp/Fax. +6224 7474698 Email : fitrianaaya88@ gmail.com

\begin{abstract}
ABSTRAK
Perairan Prawean Jepara, merupakan salah satu wilayah pantai dengan garis pantai terluas di pesisir Jepara. Kondisi morfologi yang terdapat pada pantai ini memiliki komunitas padang lamun yang relatif subur yang mempengaruhi kelimpahan larva ikan. Larva ikan merupakan tahap awal dari pertumbuhan ikan. Larva juga dipengaruhi oleh banyak faktor lingkungan bagi kelulushidupannya. Fase bulan yang berhubungan dengan pasang surut akan mempengaruhi hasil dari kelimpahan larva ikan. Penelitian ini bertujuan untuk mengetahui jenis dan kelimpahan larva ikan pada kerapatan lamun di fase bulan yang berbeda. Penelitian dilaksanakan pada bulan Maret - April 2018. Metode yang digunakan adalah metode survei dengan penentuan titik sampling menggunakan metode purposive sampling di 3 stasiun baik pada saat pasang dan surut di fase bulan berbeda. Hasil yang diperoleh menunjukkan bahwa jumlah larva ikan yang tertangkap sebanyak 1382 ind/900 $\mathrm{m}^{3}$ terdiri dari 8 famili yakni: Apogonidae (7), Blennidae (415), Engraulidae (34), Gobiidae (521), Lutjanidae (218), Mugillidae (60), Mullidae (25) dan Nemipteridae (102). Larva famili yang tertangkap secara keseluruhan, Gobbidae (larva yang paling banyak tertangkap) dan Apogonidae (jumlah paling sedikit). Nilai korelasi antara kelimpahan larva ikan dengan kerapatan lamun yaitu sebesar $r=0,546 ; 0,628 ; 0,784$ dan 0,791. Berdasarkan hal tersebut dapat disimpulkan bahwa terdapat hubungan yang erat antara kelimpahan dan komposisi famili larva ikan dengan kerapatan lamun.
\end{abstract}

Kata kunci: Kelimpahan; Larva ikan; Fase Bulan; Padang Lamun; Perairan Prawean Jepara.

\section{ABSTRACT}

Prawean Jepara waters are one of the coastal areas with the widest coastline on the coast of Jepara. The morphological conditions found on this beach relatively has fertile seagrass communities that affect the abundance of fish larvae. Fish larvae is the initial stage of fish growth. Larvae is also influenced by many environmental factors for their life. The phases of the moon associated with tides will affect the results of the abundance of fish larvae. This study aims to determine the type and abundance of fish larvae in seagrass density in different moon phases. The study was conducted in March - April 2018. The method used was a survey method with the determination of sampling points using purposive sampling method at 3 stations both at high tide and low tide in different moon phases. The results obtained showed that the number of fish larvae caught was 1382 ind/900m ${ }^{3}$ consisting of 8 families: Apogonidae (7), Blennidae (415), Engraulidae (34), Gobiidae (521), Lutjanidae (218), Mugillidae (60) , Mullidae (25) and Nemipteridae (102). The family find overall larvae, Gobbidae (the most caught larvae) and Apogonidae (is the least caught larvae). The correlation value between the abundance of fish larvae with seagrass density is equal to $r=0.546 ; 0.628 ; 0.784$ and 0.791. Based on this, it can be concluded that there is a close relationship between abundance and composition of fish larvae families with seagrass density.

Keywords: Abundance; Fish larvae; Phase of the Moon; Seagrass; Prawean Jepara Waters. *) Penulis Penanggungjawab

\section{PENDAHULUAN}

Larva ikan merupakan awal fase masa kritis bagi ikan, dimana pembentukan organ tubuh belum terbentuk secara sempurna. Salah satu habitat yang cocok yaitu ekosistem lamun, hal ini dikarenakan ekosistem lamun merupakan daerah nursery ground, spowning ground dan feeding ground. Perbedaan tingkat kerapatan lamun (padat, sedang, jarang) dapat memberikan pengaruh terhadap komposisi dan kelimpahan larva ikan. Hubungan antara kelimpahan larva ikan dengan tingkat kerapatan lamun dapat dijadikan informasi pengelolaan sumberdaya yang berkelanjutan.

Penelitian di bidang kehidupan larva ikan di Indonesia masih cukup jarang sehingga belum memberikan sumbangan yang signifikan dalam manajemen perikanan yang berbasis pengelolaan yang berkelanjutan 
(sustainable fisheries). Dengan melakukan penelitian larva ikan dalam jangka waktu yang panjang maka kita akan dapat mengetahui informasi mengenai sebaran kelimpahan larva.

Penelitian dillakukan pada tanggal 25 Maret - 15 April 2018 dengan interval waktu seminggu dalam satu bulan. Tujuan penelitian yang dilakukan untuk mengetahui kelimpahan larva ikan berdasarkan keterkaitan antar fase bulan yang terdapat di padang lamun dan mengatahui hubungan antara kelimpahan larva ikan dengan tingkat kerapatan lamun.

\section{MATERI DAN METODE PENELITIAN}

Materi

Materi yang digunakan dalam penelitian adalah sampel larva ikan dan data kualitas air, diantaranya: kedalaman, kecerahan, $\mathrm{DO}, \mathrm{pH}$, suhu, arus dan salinitas. Alat yang digunakan untuk sampling adalah Seine Net dengan mesh size $1 \mathrm{~mm}$, botol sampel; kertas label; alat tulis dan kamera digital. GPS; termometer air raksa; Secchi disk; current meter; DO; refraktometer; $\mathrm{pH}$ paper, buku identifikasi larva ikan; penggaris; mikroskop stereo; cawan petri; alat sectio; dan alat tulis. Bahan yang digunakan dalam penelitian ini adalah formalin dengan perbandingan $4 \%$ untuk mengawetkan larva ikan dan data pasang surut.

\section{Metode}

Metode yang digunakan dalam penelitian ini adalah metode survei. Menurut Nazir (1999), metode survei adalah penyelidikan yang diadakan untuk memperoleh fakta dari gejala yang ada dan mencari keterangan secara faktual. Penelitian ini dilakukan untuk memperoleh data tentang kelimpahan larva ikan berdasarkan pasang surut serta data penunjangnya.

\section{Penentuan Lokasi Sampling}

Pantai Prawean merupakan lokasi sampling dan pengambilan data. Alasan melakukan penelitian di Pantai Prawean adalah Pantai Prawean merupakan salah satu pantai dengan kerapatan lamun yang sangat subur dibandingkan beberapa pantai yang ada di Jepara. Metode yang digunakan dalam pengambilan sampel adalah metode purposive sampling yaitu dianggap bahwa sampel yang diambil dapat mewakili populasi. Menurut Sugiyono (2010), Penentuan titik sampling menggunakan metode purposive sampling yaitu teknik penentuan/pengambilan sampel dengan sengaja dan berdasarkan suatu pertimbangan dan tujuan tertentu. Penentuan stasiun sampling beradasarkan persentase penutupan dan tingkat kerapatan lamun yang dilakukan di 3 stasiun meliputi stasiun A di ekosistem lamun yang memiliki tingkat kerapatan yang tinggi; stasiun B di ekosistem lamun yang memiliki tingkat kerapatan yang sedang; dan stasiun C di ekosistem lamun yang memiliki tingkat kerapatan yang rendah. Peta penelitian tersaji pada gambar 1.

\section{Pengambilan Sampel Larva Ikan}

Metode pengambilan sampel larva ikan dilakukan secara pasif yaitu dengan menarik jaring yang dilakukan oleh manusia pada jarak dan luasan tertentu, dengan menggunakan Seine Net yang berukuran 2 x 1 meter. Jaring Seine Net berukuran 2 x 1 meter dengan mesh size $1 \mathrm{~mm}$ ditarik sejauh 25 meter setiap titiknya (Saraswati, 2016). Pengambilan sampel larva ikan dilakukan sebanyak 9 titik. Sampling dilakukan secara tegak lurus dan berlawanan dengan arus dengan masing-masing dilakukan 2 kali penarikan. Pengambilan sampel dilakukan pada tanggal 25 Maret - 15 April 2018 dengan interval waktu seminggu dalam satu bulan. Gambar 1 . Peta lokasi penelitian di Pantai Prawean, Bandengan Jepara.

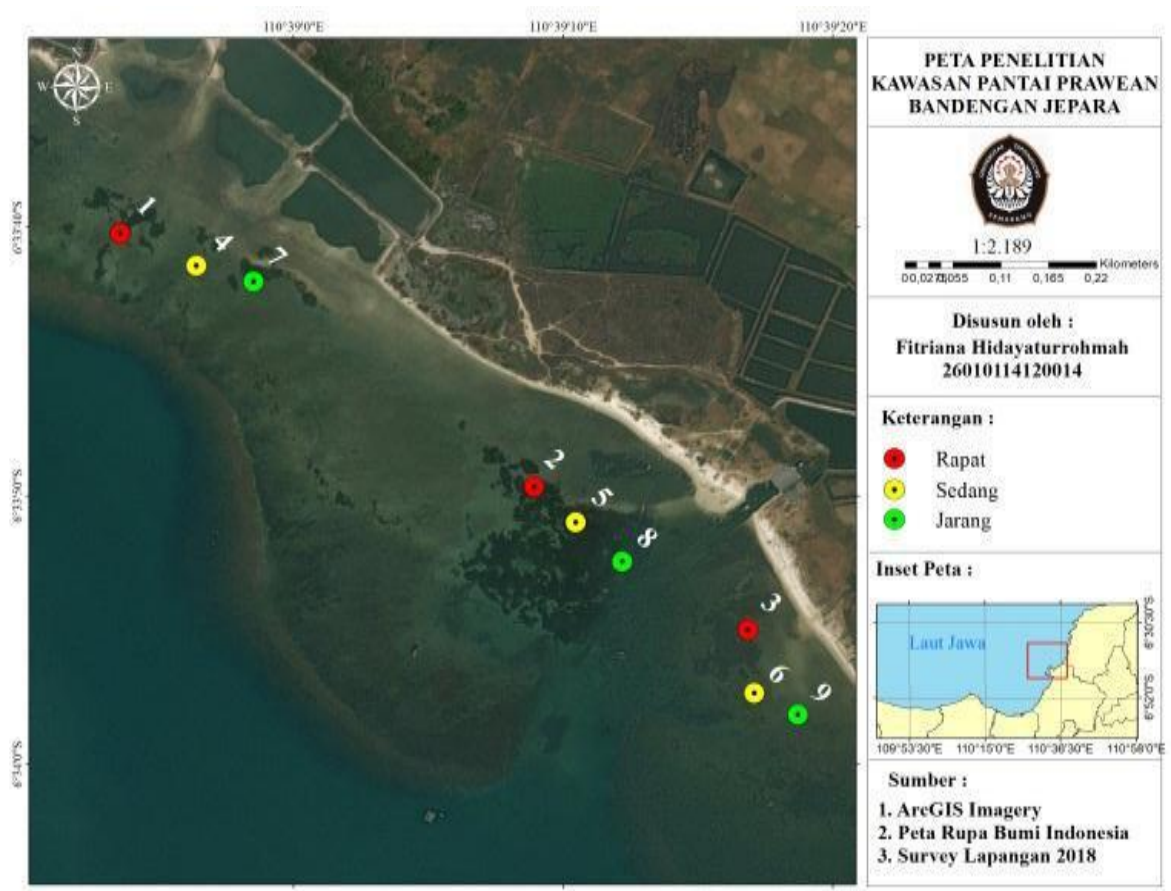

Gambar 1. Peta lokasi penelitian 


\section{Analisis Data \\ Analisis Regresi Linier Berganda}

Analisis data yang digunakan untuk menetukan hubungan antara kelimpahan larva ikan dengan kerapatan lamun, yaitu analisis regresi dan korelasi dengan menggunakan software SPSS versi 22. Analisis yang digunakan adalah analisis regresi linier berganda. Menurut Santoso (2011), analis regresi linier adalah hubungan secara linier antara satu variabel independen $(\mathrm{X})$ dengan variabel dependen $(\mathrm{Y})$ dalam artian ada variabel yang mempengaruhi dan ada variabel yang dipengaruhi.

\section{Kelimpahan Larva Ikan}

Kelimpahan larva ikan didefinisikan sebagai banyaknya larva ikan per satuan volume daerah pengambilan (Taufik, 2012). Dihitung menggunakan rumus sebagai berikut:

Keterangan:

$$
\mathrm{N}=\mathrm{n} / \mathrm{Vtsr}
$$

$$
\begin{aligned}
& \mathrm{N}=\text { Kelimpahan larva ikan (ind } / \mathrm{m}^{3} \text { ) } \\
& \mathrm{n}=\text { Jumlah larva ikan yang didapat (ind) } \\
& \text { Vtsr = Volume air tersaring (Vtsr }=\text { luas jaring } \mathrm{x} \text { panjang penarikan) }
\end{aligned}
$$

\section{Analisis Indeks Keanekaragaman, Keseragaman, Dominasi, dan Kelimpahan Larva Ikan}

Indeks keanekaragaman dapat diartikan sebagai suatu penggambaran secara sistematik yang melukiskan struktur komunitas untuk memudahkan proses analisis informasi-informasi mengenai macam dan jumlah organisme. Semakin banyak jenis yang ditemukan, maka keanekaragaman semakin besar; meskipun nilai ini sangat tergantung dari jumlah individu masing-masing jenis. Menurut Odum (1993), untuk perhitungan keanekaragaman digunakan indeks Shannon-Wiener:

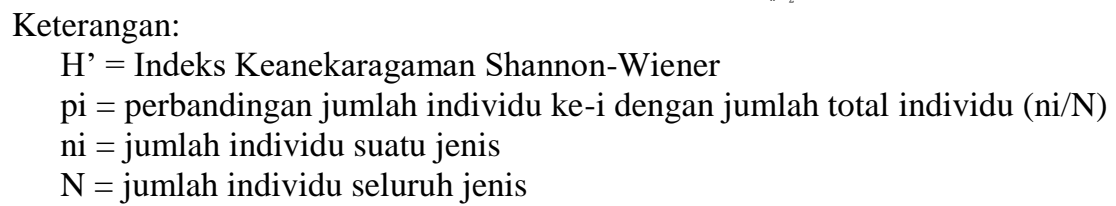

Kriteria indeks keanekaragaman dibagi dalam 3 kategori yaitu:

$\mathrm{H}^{\prime}<1 \quad$ : Keanekaragaman jenis rendah

$1<\mathrm{H}^{\prime}<3 \quad$ : Keanekaragaman jenis sedang

$\mathrm{H}^{\prime}>3 \quad$ : Keanekaragaman jenis tinggi

Indeks keseragaman (e) merupakan pendugaan yang baik untuk menentukan dominasi dalam suatu area, apabila satu atau beberapa jenis melimpah dari yang lainnya maka indeks keseragaman akan rendah.

Menurut Poole (1974) dalam Supono (2008), keseragaman jenis dapat dibandingkan dengan indeks keseragaman yaitu dengan nilai maksimumnya, menggunakan rumus sebagai berikut:

$\mathrm{e}=$

Keterangan:

$$
\begin{aligned}
& \mathrm{e}=\text { Indeks keseragaman } \\
& \mathrm{H}^{\prime}=\text { Indeks keanekaragaman Shannon-Wiener } \\
& \mathrm{H} \max =\log _{2} \mathrm{~S}=\text { Indeks keanekaragaman maksimum } \\
& \mathrm{s}=\text { Jumlah maksimum }
\end{aligned}
$$

Indeks dominasi (D) digunakan untuk mengetahui sejauh mana suatu spesies atau genus mendominasi suatu komunitas pada tiap habitat. Perhitungan indeks dominansi menggunakan rumus menurut Odum (1993) sebagai berikut:

Keterangan:

$$
\mathrm{D}=\sum(-)^{2}
$$

$\mathrm{D}=$ Indeks Dominansi Simpson $(0-1,0)$

$\mathrm{ni}=$ Jumlah individu ke $\mathrm{i}$

$\mathrm{n}=$ Jumlah total individu

Angka D berkisar antara 0,0-1,0 apabila angka D mendekati 0,0 berarti hampir tidak ada individu yang mendominasi dan biasanya diikuti angka e yang besar (mendekati 1); sedangkan apabila angka D mendekati 1 berarti terjadi dominasi spesies tertentu dan dicirikan dengan angka e yang lebih kecil atau mendekati 0.

\section{HASIL DAN}

\section{PEMBAHASAN Hasil}

\section{Gambaran Umum Lokasi Penelitian}

Lokasi penelitian berada di wilayah Pantai Prawean yang terletak di Desa Bandengan Kecamatan Jepara, Kabupaten Jepara. Desa Bandengan merupakan salah satu desa di wilayah Kecamatan Jepara 
terletak di sebelah utara. Secara geografis terletak pada koordinat $\left(6^{\circ} 33^{\prime} 12.15^{\prime \prime S}\right.$ - 110³8'49.04"E dan $6^{\circ} 33^{\prime} 1.57^{\prime \prime} \mathrm{S}$ - 110³9'15.07"E). Pantai Prawean mengalami tekanan dari berbagai aktivitas manusia, dan juga perairan tersebut menjadi jalur transportasi kapal para nelayan setempat yang mencari ikan. Keadaan yang demikian dikhawatirkan akan mempengaruhi produktivitas perairan dan secara tidak langsung mempengaruhi kondisi ekosistem lamun di perairan (Finishia et al., 2014).

\section{Variabel Kualitas Perairan di Lokasi Penelitian}

Variabel kualitas air yang diamati di lokasi penelitian meliputi kecerahan, kedalaman, suhu air, kecepatan arus, salinitas, pH dan DO (Dissolve Oxygen). Lokasi antara stasiun satu dengan lainnya dibedakan berdasarkan kerapatan lamun. Kisaran Data Variabel Kualitas Air di Pantai Prawean saat Pasang dan saat surut tersaji pada Tabel 1 dan Tabel 2.

Tabel 1. Kisaran Data Variabel Kualitas Air di Pantai Prawean saat Pasang

\begin{tabular}{cccccccc}
\hline Stasiun & Kecerahan & Kedalaman & Temperatur & Arus & pH & Salinitas & DO \\
\hline \multirow{3}{*}{ A } & $33-50$ & $87-120$ & $26-31$ & $0,04-0,05$ & 7 & $30-33$ & $5,83-7,31$ \\
& $35-51$ & $90-124$ & $27-32$ & $0,02-0,04$ & 8 & $30-32$ & $6,00-7,41$ \\
& $37-38$ & $89-98$ & $27-32$ & $0,03-0,05$ & 8 & $29-30$ & $5,90-6,67$ \\
\hline \multirow{3}{*}{ B } & $33-52$ & $87-120$ & $27-32$ & $0,02-0,05$ & 7 & $30-33$ & $5,83-7,30$ \\
& $35-48$ & $93-116$ & $27-32$ & $0,02-0,03$ & 8 & $30-32$ & $6,10-7,20$ \\
& $34-40$ & $87-92$ & $27-32$ & $0,03-0,05$ & 8 & $29-30$ & $5,81-6,07$ \\
\hline \multirow{3}{*}{$\mathbf{C}$} & $32-47$ & $87-115$ & $26-31$ & 0,02 & 7 & $30-33$ & $5,87-7,17$ \\
& $33-47$ & $89-113$ & $27-32$ & 0,02 & 8 & $30-32$ & $5,83-7,11$ \\
& $34-40$ & $83-90$ & $27-32$ & 0,02 & 8 & $29-30$ & $5,70-5,90$ \\
\hline
\end{tabular}

Kecerahan saat pasang di ketiga stasiun berkisar antara $32-52 \mathrm{~cm}$. Nilai kedalaman pada semua stasiun penelitian berkisar antara $83-124 \mathrm{~cm}$. Kisaran nilai temperatur pada lokasi penelitian sekitar $26-32$ $\left({ }^{\circ} \mathrm{C}\right)$ dan kisaran nilai temperatur di stasiun A dan $\mathrm{C}$ sangat stabil yaitu $26-32\left({ }^{\circ} \mathrm{C}\right)$. Arus di lokasi penelitian berkisar antara $0,02-0,05 \mathrm{~m} / \mathrm{s}$. Nilai pH pada lokasi penelitian berkisar 7- 8. Salinitas di lokasi penelitian berkisar antara 29 - 33 (\%). Nilai rata-rata DO (Disolved Oxygen) pada lokasi penelitian berkisar antara 5,70 - 7,41 mg/l, dimana nilai terendah berada pada stasiun C sebesar 5,70 mg/l.

Tabel 2. Kisaran Data Variabel Kualitas Air di Pantai Prawean saat Surut

\begin{tabular}{cccccccc}
\hline Stasiun & Kecerahan & Kedalaman & Temperatur & Arus & $\mathrm{pH}$ & Salinitas & DO \\
\hline \multirow{3}{*}{ A } & $\sim$ & $42-50$ & $26-30$ & $0,03-0,05$ & 7 & $30-31$ & $5,30-5,47$ \\
& $\sim$ & $40-70$ & $25-30$ & $0,02-0,03$ & 8 & $29-30$ & $5,27-5,50$ \\
& $\sim$ & $30-45$ & $25-29$ & $0,03-0,05$ & 8 & $28-29$ & $5,01-5,37$ \\
\hline \multirow{3}{*}{ B } & $\sim$ & $31-45$ & $26-30$ & $0,02-0,03$ & 7 & $30-31$ & $5,13-5,39$ \\
& $\sim$ & $37-47$ & $25-30$ & 0,02 & 8 & $29-30$ & $5,19-5,43$ \\
& $\sim$ & $35-38$ & $25-29$ & $0,02-0,03$ & 8 & $28-29$ & $5,07-5,13$ \\
\hline \multirow{3}{*}{ C } & $\sim$ & $30-47$ & $26-30$ & 0,02 & 7 & $30-31$ & $5,01-5,41$ \\
& $\sim$ & $38-43$ & $25-30$ & 0,02 & 8 & $29-30$ & $5,19-5,31$ \\
& $\sim$ & $29-33$ & $25-29$ & $0,01-0,02$ & 8 & $28-29$ & $5,01-5,03$ \\
\hline
\end{tabular}

Kecerahan di ekosistem lamun Pantai Prawean saat surut di ketiga lokasi nilainya tak terhingga, sehingga substrat yang ada di pantai Prawean terlihat jelas. Nilai kedalaman pada ketiga lokasi penelitian berkisar antara 29 - $70 \mathrm{~cm}$, dimana di stasiun C titik 9 merupakan lokasi dengan kedalaman terendah yaitu $29 \mathrm{~cm}$. Kisaran nilai temperatur pada lokasi penelitian sekitar $25-30\left({ }^{\circ} \mathrm{C}\right)$. Arus di lokasi penelitian berkisar antara $0,01-0,05 \mathrm{~m} / \mathrm{s}$. Nilai arus terendah pada stasiun $\mathrm{C}$ titik 9 yaitu $0,01 \mathrm{~m} / \mathrm{s}$. Nilai pH pada lokasi penelitian berkisar 7- 8. Salinitas di lokasi penelitian berkisar antara 28 - 31 (\%o). Nilai rata-rata DO (Disolved Oxygen) pada lokasi penelitian berkisar antara 5,01 - 5,50 $\mathrm{mg} / \mathrm{l}$, dimana nilai terendah berada pada lokasi stasiun A dan C di titik 3,7 dan 9 yaitu sebesar 5,01 mg/l.

\section{Komposisi Larva Ikan}

Total Jumlah larva ikan yang berhasil diidentifikasi di kawasan pantai Prawean, Jepara sebanyak 1.382 ind $/ 900 \mathrm{~m}^{3}$ larva pasang dan larva surut yang terdiri dari 8 famili. Jenis larva ikan yang tertangkap adalah Apogonidae, Blennidae, Engraulidae, Gobiidae, Lutjanidae, Mugillidae, Mullidae dan Nemipteridae. Jumlah Famili, Individu dan Kelimpahan Relatif Larva Ikan selama Penelitian tersaji pada Tabel 3. 
Tabel 3. Jumlah Famili, Individu dan Kelimpahan Relatif Larva Ikan selama Penelitian

\begin{tabular}{lcrrrr}
\hline \multirow{2}{*}{ No } & \multirow{2}{*}{ Famili } & \multicolumn{2}{c}{ Pasang } & \multicolumn{2}{c}{ Surut } \\
\cline { 2 - 6 } & & Jml Indiv & KR (\%) & Jml Indiv & \multicolumn{1}{c}{ KR (\%) } \\
\hline 1 & Apogonidae & 7 & 0,81 & 0 & 0,00 \\
2 & Blennidae & 256 & 29,63 & 159 & 30,69 \\
3 & Engraulidae & 16 & 1,85 & 18 & 3,47 \\
4 & Gobiidae & 354 & 40,97 & 167 & 32,24 \\
5 & Lutjanidae & 146 & 16,90 & 72 & 13,90 \\
6 & Mugillidae & 23 & 2,66 & 37 & 7,14 \\
7 & Mullidae & 13 & 1,50 & 12 & 2,32 \\
8 & Nemipteridae & 49 & 5,67 & 53 & 10,23 \\
\hline$\sum$ & 8 & 864 & 100,00 & 518 & 100,00 \\
\hline
\end{tabular}

Tabel 3. menunjukkan bahwa famili Gobiidae merupakan jenis yang paling banyak tertangkap pada saat pasang sebanyak 40,97 \%, dan 32,24\% pada saat surut. Famili Apogonidae didapatkan dalam jumlah yang sedikit yaitu $0,81 \%$ pada saat pasang dan $0 \%$ pada saat surut. Jenis dan Jumlah Larva Ikan yang Tertangkap berdasarkan Fase Bulan tersaji pada Tabel 4.

Tabel 4. Jenis dan Jumlah Larva Ikan (ind/ $1200 \mathrm{~m}^{3}$ ) yang Tertangkap berdasarkan Fase Bulan

\begin{tabular}{rcrrrr}
\hline No & Famili & $\begin{array}{c}\text { Bulan } \\
\text { Baru }\end{array}$ & $\begin{array}{c}\text { Bulan } \\
\text { seperempat }\end{array}$ & $\begin{array}{c}\text { Bulan } \\
\text { Purnama }\end{array}$ & $\begin{array}{c}\text { Bulan } \\
\text { Tigaperempat }\end{array}$ \\
\hline 1 & Apogonidae & 4 & 0 & 0 & 3 \\
2 & Blennidae & 65 & 177 & 63 & 110 \\
3 & Engraulidae & 15 & 0 & 5 & 14 \\
4 & Gobiidae & 70 & 139 & 121 & 191 \\
5 & Lutjanidae & 49 & 62 & 55 & 52 \\
6 & Mugillidae & 0 & 53 & 4 & 3 \\
7 & Mullidae & 9 & 2 & 3 & 11 \\
8 & Nemipteridae & 19 & 58 & 11 & 14 \\
\hline$\sum$ & 8 & 231 & 491 & 262 & 398 \\
\hline
\end{tabular}

Komposisi larva ikan yang tertangkap di ketiga stasiun penelitian memiliki perbedaan. Namun berdasarkan fase bulan, jumlah individu larva ikan yang diperoleh pada bulan seperempat dan tigaperempat lebih besar dibandingkan pada bulan baru dan bulan purnama.

Kelimpahan Larva Ikan (ind $/ \mathbf{m}^{3}$ )

Tabel 6. Rata-rata Kelimpahan Larva Ikan $\left(\mathrm{ind} / \mathrm{m}^{3}\right.$ ) pada 9 Titik pada Saat Pasang dan Surut

\begin{tabular}{ccrrrrrr}
\hline \multirow{2}{*}{ Fase Bulan } & \multirow{2}{*}{ Kelimpahan } & \multicolumn{3}{c}{ Pasang } & \multicolumn{3}{c}{ Surut } \\
\cline { 3 - 8 } & & \multicolumn{1}{c}{ Padat } & \multicolumn{1}{c}{ Sedang } & Jarang & Padat & Sedang & Jarang \\
\multirow{2}{*}{ Bulan Baru } & $\mathrm{n}$ (ind) & 70 & 40 & 20 & 51 & 32 & 18 \\
& $\mathrm{~N}(\mathrm{ind} / 100 \mathrm{~m} 3)$ & 35 & 20 & 10 & 25,5 & 16 & 9 \\
\hline \multirow{2}{*}{ Bulan Seperempat } & $\mathrm{n}$ (ind) & 157 & 126 & 20 & 140 & 42 & 6 \\
& $\mathrm{~N}(\mathrm{ind} / 100 \mathrm{~m} 3)$ & 78,5 & 63 & 10 & 70 & 21 & 3 \\
\hline \multirow{2}{*}{ Bulan Purnama } & $\mathrm{n}($ ind) & 99 & 42 & 18 & 69 & 20 & 14 \\
& $\mathrm{~N}(\mathrm{ind} / 100 \mathrm{~m} 3)$ & 49,5 & 21 & 9 & 34,5 & 10 & 7 \\
\hline Bulan & $\mathrm{n}$ (ind) & 170 & 88 & 14 & 73 & 37 & 16 \\
Tigaperempat & $\mathrm{N}(\mathrm{ind} / 100 \mathrm{~m} 3)$ & 85 & 44 & 7 & 36,5 & 18,5 & 8 \\
\hline
\end{tabular}

Kelimpahan rata-rata larva ikan yang dihasilkan di tiga stasiun pada saat pasang dan surut menunjukkan bahwa stasiun A yang memliki kerapatan lamun yang padat pada saat pasang di fase bulan tigaperempat memiliki kelimpahan yang paling tinggi $\left(85 \mathrm{ind} / 100 \mathrm{~m}^{3}\right)$ dan yang paling rendah adalah stasiun $\mathrm{C}$ yang memliki kerapatan lamun jarang pada saat pasang di fase bulan seperempat pada saat surut $\left(3 \mathrm{ind} / 100 \mathrm{~m}^{3}\right)$. Lebih jelasnya dapat dilihat pada gambar 2 .

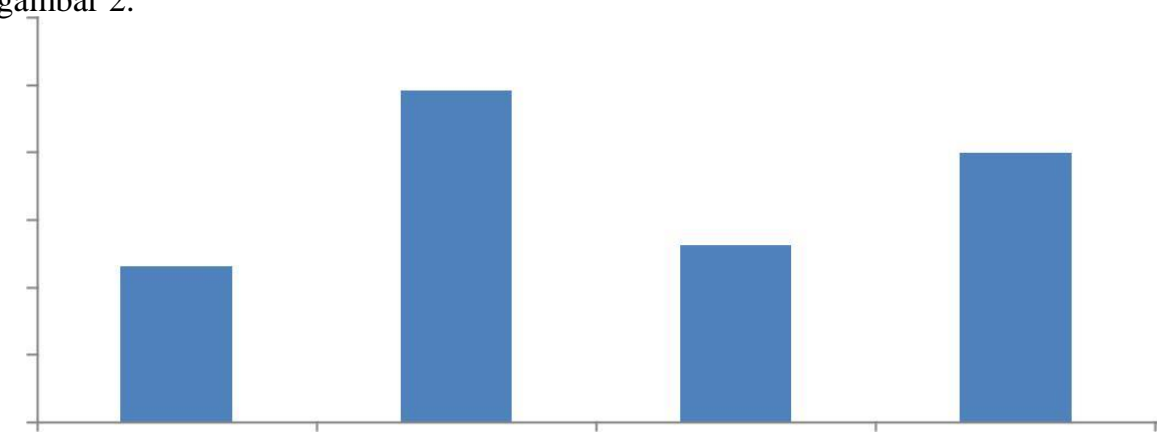

Bulan Baru Bulan seperempat Bulan Purnama Bulan tigaperempat Gambar 2. Fluktuasi Kelimpahakton Krustasea pada Tiga Stasiun Penelitian. 
Berdasarkan Gambar 2 di atas, terlihat bahwa kelimpahan larva ikan dari 8 famili yang paling banyak diperoleh selama penelitian pada fase bulan tigaperempat dan yang paling jarang diperoleh selama penelitian pada fase bulan baru. Penurunan kelimpahan larva ikan pada bulan baru diduga karena adanya faktor lain berupa kondisi lingkungan di lapangan yang berbeda dengan kondisi lingkungan pada ketiga fase lainnya.

\section{Kerapatan Lamun}

Kerapatan dan distribusi jenis lamun di lokasi penelitian secara keseluruhan disajikan pada Tabel 5. Tabel 5. Total Kerapatan Jenis Lamun di semua stasiun

\begin{tabular}{|c|c|c|c|c|c|c|}
\hline \multirow[b]{2}{*}{ Stasiun } & \multicolumn{5}{|c|}{ Jenis Lamun (Ind/m²) } & \multirow{2}{*}{$\begin{array}{c}\text { Total } \\
\left(\text { Ind } / \mathbf{m}^{2}\right)\end{array}$} \\
\hline & $\mathbf{E a}$ & Th & Cs & $\mathrm{Cr}$ & $\mathrm{Hu}$ & \\
\hline $\mathrm{A}$ & 19 & 652 & 25 & 594 & 270 & 1560 \\
\hline B & 8 & 209 & 465 & 0 & 0 & 682 \\
\hline $\mathrm{C}$ & 61 & 38 & 59 & 0 & 0 & 158 \\
\hline$\sum$ & 88 & 899 & 549 & 594 & 270 & 240 \\
\hline
\end{tabular}

Keterangan :

Ea : Enhallus acoroides; Th : Thallasia hemprichii; $\mathrm{Cs}:$ Cymodocea serrullata; $\mathrm{Cr} ;$ Cymodocea rotundata; $\mathrm{Hu}$; Halodule uninervis

Dari Tabel 5, terlihat bahwa selama penelitian ditemukan 5 spesies lamun diantaranya Enhallus acoroides, Thallasia hemprichii, Cymodocea serrullata, Cymodocea rotundata dan Halodule uninervis. Thallasia hemprichii merupakan salah satu spesies lamun yang memiliki nilai kerapatan tertinggi di semua lokasi penelitian yaitu sebanyak 899 tegakan $/ \mathrm{m}^{2}$. Spesies jenis Enhallus acoroides ditemukan paling rendah di semua lokasi penelitian yaitu sebanyak 88 tegakan $/ \mathrm{m}^{2}$.

Struktur Komunitas Larva Ikan

Tabel 6. Indeks Keanekaragaman, Keseragaman dan Dominasi Larva Ikan

\begin{tabular}{|c|c|c|c|c|c|}
\hline \multicolumn{6}{|c|}{ Bulan Baru } \\
\hline Titik Sampel & Stasiun & Keanekaragaman (H') & Keseragaman $(\mathbf{E})$ & Dominasi & (D) \\
\hline \multirow[t]{3}{*}{ Pasang } & $\mathrm{A}$ & 1,415 & 0,790 & 0,282 & \\
\hline & B & 1,336 & 0,830 & 0,301 & \\
\hline & $\mathrm{C}$ & 0,762 & 0,473 & 1,245 & \\
\hline \multirow[t]{3}{*}{ Surut } & $\mathrm{A}$ & 1,065 & 0,970 & 0,354 & \\
\hline & $\mathrm{B}$ & 1,152 & 0,640 & 0,188 & \\
\hline & $\mathrm{C}$ & 0,732 & 0,410 & 0,278 & \\
\hline \multicolumn{6}{|c|}{ Bulan seperempat } \\
\hline Titik Sampel & & Keanekaragaman (H') & Keseragaman (E) & Dominasi & (D) \\
\hline \multirow[t]{3}{*}{ Pasang } & $\bar{A}$ & 0,818 & 0,590 & 0,264 & \\
\hline & $\mathrm{B}$ & 1,010 & 0,628 & 0,298 & \\
\hline & $\mathrm{C}$ & 0,682 & 0,492 & 0,475 & \\
\hline \multirow[t]{3}{*}{ Surut } & A & 0,854 & 0,530 & 0,273 & \\
\hline & $\mathrm{B}$ & 0,826 & 0,513 & 0,223 & \\
\hline & $\mathrm{C}$ & 0,868 & 0,790 & 0,500 & \\
\hline
\end{tabular}

\begin{tabular}{|c|c|c|c|c|c|}
\hline \multicolumn{6}{|c|}{ Bulan Purnama } \\
\hline Titik Sampel & & Keanekaragaman (H') & Keseragaman $(\mathbf{E})$ & Dominasi & (D) \\
\hline \multirow[t]{2}{*}{ Pasang } & $\overline{\mathrm{A}}$ & 0,108 & 0,060 & 0,326 & \\
\hline & $\mathrm{B}$ & 0,755 & 0,688 & 0,579 & \\
\hline & $\mathrm{C}$ & 1,244 & 0,863 & 0,247 & \\
\hline \multirow[t]{3}{*}{ Surut } & A & 1,056 & 0,656 & 0,319 & \\
\hline & $\mathrm{B}$ & 0,788 & 0,568 & 0,315 & \\
\hline & $\mathrm{C}$ & 1,117 & 0,694 & 0,245 & \\
\hline \multicolumn{6}{|c|}{ Bulan Tigaperempat } \\
\hline \multicolumn{2}{|l|}{ Titik Sampel } & Keanekaragaman (H') & Keseragaman $(\mathbf{E})$ & Dominasi & (D) \\
\hline \multirow[t]{3}{*}{ Pasang } & $\overline{\mathrm{A}}$ & 1,128 & 0,579 & 0,371 & \\
\hline & $\mathrm{B}$ & 0,726 & 0,524 & 0,374 & \\
\hline & $\mathrm{C}$ & 1,470 & 0,756 & 0,173 & \\
\hline \multirow[t]{3}{*}{ Surut } & A & 0,897 & 0,501 & 0,344 & \\
\hline & $\mathrm{B}$ & 1,256 & 0,780 & 0,248 & \\
\hline & $\mathrm{C}$ & 0,551 & 0,342 & 0,375 & \\
\hline
\end{tabular}

Hasil perhitungan nilai indeks keanekaragaman $\left(\mathrm{H}^{\prime}\right)$ tertinggi terdapat pada fase bulan baru pada saat pasang yaitu sebesar 1,415 di stasiun A yang tingkat kerapatan lamunnya tinggi dan terendah pada fase bulan 
tigaperempat pada saat surut yaitu sebesar 0,551 di stasiun $\mathrm{C}$ yang tingkat kerapatan lamunnya jarang. Indeks keseragaman (E) tertinggi pada fase bulan baru pada saat surut yaitu sebesar 0,97 di stasiun A yang tingkat kerapatan lamunnya tinggi dan terendah pada fase bulan purnama pada saat pasang yaitu sebesar 0,06 di stasiun A yang tingkat kerapatan lamunnya tinggi. Keseragaman ini termasuk tinggi yang didukung oleh adanya dominasi dari jenis famili tertentu pada setiap stasiun. Nilai indeks dominasi tertinggi terdapat pada fase bulan purnama pada saat pasang yaitu sebesar 0,579 di stasiun A yang tingkat kerapatan lamunnya jarang. Angka ini menunjukkan bahwa pada lokasi penelitian terdapat jenis yang mendominasi.

Hubungan Kelimpahan Larva Ikan dengan Tingkat Kerapatan Lamun yang

Berbeda Tabel 7. Kelimpahan Larva Ikan dengan Tingkat Kerapatan Lamun yang

Berbeda

\begin{tabular}{|c|c|c|c|c|}
\hline Fase Bulan & $\mathbf{R}$ & $\begin{array}{c}\mathbf{R} \\
\text { Square }\end{array}$ & $\mathbf{F}$ & Sig. \\
\hline Baru &, $739^{\mathrm{a}}$ &, 546 & 5,605 &, $042^{\mathrm{b}}$ \\
\hline Tigaperempat & $889^{\mathrm{a}}$ & 791 & 11,342 & $009^{\mathrm{b}}$ \\
\hline Purnama &, $793^{\mathrm{a}}$ & 628 & 5,070 & $051^{\mathrm{b}}$ \\
\hline Seperempat &, $885^{\mathrm{a}}$ &, 784 & 7,441 &, $024^{\mathrm{b}}$ \\
\hline
\end{tabular}

\section{Pembahasan}

\section{Komposisi dan Kelimpahan Larva Ikan}

Larva ikan yang tertangkap di pantai Prawean selama penelitian menunjukkan bahwa famili Blennidae dan Gobiidae merupakan tangkapan terbanyak dari 8 famili larva ikan yang diperoleh pada saat kondisi pasang maupun surut. Jumlah individu larva ikan yang diperoleh selama penelitian menunjukkan kondisi yang berfluktuasi. Hal ini berkaitan dengan adanya migrasi untuk mencari kondisi lingkungan yang sesuai dengan kebutuhan akan makanan serta adanya faktor arus dan pasang surut. Menurut Subiyanto et al. (2008), berdasarkan cara hidupnya yang masih digolongkan planktonik, larva ikan bergerak secara pasif, mengikuti arus air perairan di sekitarnya.

Famili yang mendominasi pada lokasi penelitian di setiap fase adalah famili Gobiidae yaitu ikan gelodok atau biasa disebut ikan beloso. Secara umum famili Gobiidae hidup ditemukan pada daerah estuaria hingga laut. Sebagian besar dari famili Gobiidae hidup di ekosistem estuaria. Hal ini didukung oleh Subiyanto et al. (2009), yang menyatakan larva Gobiidae memiliki kemampuan adaptasi yang baik terhadap lingkungan estuaria dan biasanya dominan tertangkap di perairan tersebut.

Berdasarkan penelitian, famili Blennidae hampir ditemukan di semua lokasi penelitian. Famili Blennidae banyak ditemukan saat pasang yaitu sebanyak 256 individu dan 159 individu saat surut. Larva ini banyak ditemukan di stasiun A tiap titiknya. Karena pada beberapa titik dilakukan di habitat yang berdekatan dengan terumbu karang, maka diduga ada keterkaitan antara padang lamun dan terumbu karang dalam hal migrasi ikan.

\section{Pengaruh Pasang Surut terhadap Kelimpahan Larva Ikan}

Berdasarkan penelitian di pantai Prawean tidak terdapat perbedaan kelimpahan larva ikan yang signifikan pada saat pasang dan surut. Hal ini karena air pasang membantu dalam imigrasi atau distribusi larva ikan di laut. Arus dan pasang surut membawa dan menyebarkan larva yang masih bersifat planktonik. Menurut Prianto et al. (2013), bahwa faktor hidrografi di perairan pantai atau daerah asuhan berpengaruh sebagai stimuli tingkah laku imigrasi larva ikan di antaranya adalah aliran pasang surut (tidal flux) termasuk di dalamnya kecepatan arus, salinitas (terutama untuk perairan estuari), dan juga pengaruh siklus bulan.

Menurut Subiyanto et al. (2009), perbedaan kelimpahan larva ikan setiap lokasi dapat disebabkan oleh perbedaan kedalaman air akibat tinggi pasang yang berbeda. Hal ini berpengaruh pada arus yang membawa atau memindahkan larva ikan dan selanjutnya akan mempengaruhi kelimpahan.

\section{Hubungan Fase Bulan terhadap Kelimpahan Larva Ikan}

Berdasarkan penanggalan hijriyah tahun $1439 \mathrm{H}$ atau $2018 \mathrm{M}$, pada tanggal 25 Maret 2018 dengan tanggal 7 hijriyah fase bulan memasuki bulan seperempat. Sedangkan, pada tanggal 1 April 2018 dengan tanggal 14 hijriyah bulan masuk pada fase bulan purnama. Fase bulan tigaperempat jatuh pada tanggal 8 April 2018 dengan tanggal 21 hijriyah. Kemudian fase bulan baru jatuh pada tanggal 22 hijriyah atau tanggal 16 April 2018. Famili yang diperoleh saat spring tide (pasang tertinggi) dibandingkan saat nipe tide (pasang terendah) selama penelitian tidak menunjukkan perbedaan. Perbedaan yang dapat dilihat adalah meningkatnya jumlah kelimpahan individu berdasarkan fase bulan. Berdasakan Tabel 4, nilai kelimpahan yang tinggi diperoleh pada fase bulan seperempat dan tigaperempat. Kelimpahan total individu fase bulan baru dan bulan purnama lebih kecil dibandingkan pada fase bulan seperempat dan tigaperempat. Hal ini belum bisa dipastikan akan pengaruhnya, karena kemungkinan terdapat faktor lain yang menyebabkan penurunan kelimpahan pada fase bulan baru dan bulan purnama. Ditemukannya larva ikan selama pasang tertinggi bukan berarti terkait langsung dengan fase bulan, tetapi perlu diperhatikan pula topografi pantai, daerah dimana akan berpengaruh pada keterlambatan pasang. Menurut Wibowo (2010), selain gravitasi bulan faktor-faktor yang menyebabkan pasang surut adalah kedalaman dan luas perairan, gesekan dasar, dan faktor lokal seperti topografi dasar laut. Hal ini didukung oleh 
Hutabarat dan Evans (2006), dimana gerakan arus pasang surut dari laut lepas, yang merambat ke perairan pantai akan mengalami perubahan, faktor yang mempengaruhinya antara lain adalah berkurangnya kedalaman. Faktor kedalaman akan menimbulkan gesekan dasar, yang dapat mengurangi tinggi pasang surut dan menyebabkan keterlambatan fase (phase log) serta mengakibatkan persamaan non linier terhadap gelombang pasang surut, sehigga semakin dangkal perairan maka semakin besar pengaruh gesekannya. Hal tersebut diduga mengakibatkan adanya fenomena keterlambatan pasang dan surut yang berpengaruh terhadap fenomena keterlambatan pasang purnama (spring tide) dan pasang perbani (neap tide) sehingga berpengaruh terhadap tangkapan larva ikan pada bulan tersebut.

\section{Struktur Komunitas Larva Ikan}

Indeks keanekaragaman (H') yang diperoleh berdasarkan perhitungan pada setiap titik menunjukkan angka yang cukup beragam. Kisaran nilai keanekaragaman (H') pada lokasi penelitian yaitu 0,108 - 1,415 (Tabel 6) termasuk dalam kriteria angka keanekaragaman $1<\mathrm{H}^{\prime}<2$ sehingga dapat ditarik kesimpulan bahwa nilai $\mathrm{H}^{\prime}$ larva ikan yang tertangkap selama kegiatan penelitian dapat digolongkan ke dalam keanekaragaman jenis sedang. Menurut Septian et al. (2016) bahwa keanekaragaman mempunyai nilai tertinggi jika semua individu berasal dari spesies yang berbeda-beda, sebaliknya nilai terkecil diperoleh jika individu berasal dari spesies yang sama. Hal ini berarti dalam suatu komunitas, jumlah individu setiap spesiesnya relatif sama atau seragam sehingga tidak ada spesies tertentu yang mendominasi.

Indeks keseragaman (E) digunakan untuk mengetahui berapa besar kesamaan penyebaran jumlah individu setiap genus pada tingkat komunitas ditiap lokasi penelitian. Hasil analisis menunjukkan bahwa nilai indeks keseragaman di kawasan Pantai Prawean Jepara berkisar antara 0,06 - 0,97 (Tabel 6). Menurut perhitungan Shannon-Weaner nilai indeks keseragaman yang lebih dari 0,6 akan masuk kedalam kategori tinggi, nilai indeks kurang dari 0,4 - 0,6 akan masuk dalam kategori sedang (Odum, 1998).

Indeks dominasi (D) digunakan untuk mengetahui ada atau tidaknya spesies tertentu yang mendominasi suatu ekosistem. Nilai indeks dominasi larva ikan yang ada di Pantai Prawean Jepara berkisar antara 0,173 1,245 (Tabel 6). Namun, nilai dominasi di empat fase dan di tiga stasiun menunjukkan nilai dominasinya rendah. Hal ini dikarenakan nilai yang didapatkan lebih banyak mendekati 0 dibanding mendekati 1 . Nilai dominasi yang mendekati 1 menunjukkan bahwa pada lokasi penelitian terdapat jenis yang mendominasi yaitu larva famili Gobbidae. Menurut Dhahiyat et al. (2009), bila dalam suatu struktur komunitas biota yang diamati terdapat spesies yang mendominasi, maka hal ini menunjukkan bahwa komunitas berada dalam keadaan labil atau sedang terjadi tekanan ekologis.

\section{Hubungan Kelimpahan Larva Ikan terhadap Penutupan Lamun}

Berdasarkan hasil yang diperoleh dari Tabel 7, nilai korelasi menunjukkan adanya hubungan antara kelimpahan larva ikan dengan kerapatan lamun. Menurut Tataming et al. (2014), koefisien korelasi digunakan untuk mengetahui kuatnya hubungan antara variabel dependen dengan variabel independen diukur dengan koefisien korelasi (r) adalah suatu ukuran relatif dari asosiasi diantara dua variabel. Nilai korelasi antara kelimpahan larva ikan dengan kerapatan lamun di fase bulan baru, seperempat, purnama dan tigaperempat yaitu r berkisar antara 0,739 - 0,889. Menurut Young (1982) dalam Sulaiman (2002) dengan pedoman kisaran korelasi 0,70 hingga 1,00 menunjukkan adanya hubungan yang tinggi. Hal tersebut dapat disimpulkan bahwa kelimpahan larva ikan dengan kerapatan lamun memiliki hubungan yang kuat. Semakin tinggi nilai kerapatan lamun maka semakin tinggi pula nilai kelimpahan larva ikan.

\section{KESIMPULAN}

Kesimpulan yang dapat diambil dari penelitian ini adalah Larva ikan yang teridentifikasi terdiri dari 8 famili yaitu Apogonidae, Blennidae, Engraulidae, Gobiidae, Lutjanidae, Mugillidae, Mullidae dan Nemipteridae. Jumlah larva ikan yang tertangkap selama penelitian secara keseluruhan berjumlah 1.382 ind/900 ${ }^{3}$ dengan $^{2}$ definisi $231 \mathrm{ind} / 1200 \mathrm{~m}^{3}$ larva saat bulan baru, $491 \mathrm{ind} / 1200 \mathrm{~m}^{3}$ larva saat bulan seperempat, $262 \mathrm{ind} / 1200 \mathrm{~m}^{3}$ saat bulan purnama dan $398 \mathrm{ind} / 1200 \mathrm{~m}^{3}$ saat bulan tigaperempat. Kerapatan lamun dengan kelimpahan larva ikan pada pada fase bulan baru, seperempat, purnama dan tigaperempat memiliki hubungan yang kuat dengan nilai koefisien korelasi (r) 0,546;0,628; 0,784 dan 0,791. Semakin tinggi nilai kerapatan lamun maka semakin tinggi pula nilai komposisi dan kelimpahan larva ikan. Begitu pula sebaliknya.

\section{UCAPAN TERIMAKASIH}

Ucapan terimakasih ditujukan kepada Ir. Anhar Solichin, M.Si dan Oktavianto Eko Jati, S.Pi, M.Si yang telah memberikan saran dan kritik yang sangat bermanfaat bagi penulis. Kepada semua pihak yang telah membantu sehingga penulis dapat menyelesaikan artikel ini.

\section{DAFTAR PUSTAKA}

Dhahiyat, Y., Sinuhaji, dan H. Hamdani. 2009. Struktur Komunitas Ikan Karang di Daerah Transplantasi Karang Pulau Pari Kepulauan Seribu [Community Structure of Coral Reef Fish in the Coral Transplantation Area Pulau Pari Kepulauan Seribu]. Jurnal Ikhtiologi Indonesia. III (2):87-94. 
Finishia, T., I. Riniatsih dan H. Endrawati. 2014. Struktur Komunitas Polychaeta pada Ekosistem Padang Lamun Alami dan Buatan di Perairan Pantai Prawean Bandengan, Jepara. Journal Of Marine Research. 3(4).

Hutabarat, S. dan S. M. Evans, 2006. Pengantar Oseanografi. Universitas Indonesia Press, Jakarta.

Misbahudin dan I. Hasan. 2013. Analisis Data Penelitian dengan Statistik. Jakarta, Bumi Aksara.

Nazir, M. 1999. Metode Penelitian. Ghalia Indonesia, Jakarta. 622 hlm.

Odum, P. E. 1993. Dasar-dasar Ekologi: Alih Bahasa Tjahjono Samingan. Edisi Ketiga Universitas Gajah Mada. Yogyakarta. 697 hlm.

Prianto, E., S. Nurdawaty dan M. M. Kamal. 2013. Distribusi, Kelimpahan dan Variasi Ukuran Larva Ikan di Estuari Sungai Musi. Jurnal Bawal. Vol V(2):73-79.

Santosa, S. 2011. Mastering SPSS. PT. Elex Media Komputindo, Jakarta.

Saraswati, A. Solichin, A.Hartoko dan S. R. Suharti. 2016. Hubungan Kerapatan Lamun dengan Kelimpahan Larva Ikan di Pulau Pramuka, Kepulauan Seribu Jakarta. Diponegoro Journal Of Maquares. 5 (3): 111118.

Subiyanto, Ruswahyuni, dan D. G. Cahyono. 2008. Komposisi dan Distribusi Larva Ikan Pelagis di Estuaria Pelawangan Timur Segara Anakan Cilacap. Jurnal Saintek Perikanan. IV (1):62-68.

Subiyanto, N, Widyorini, dan Ruswahyuni. 2009. Pengaruh Pasang Surut terhadap Rekruitmen Larva Ikan di Pelawangan Timur Segara Anakan Cilacap. Jurnal Saintek Perikanan. 5(1): 35-39.

Sulaiman, W. 2002. Jalan Pintas Menguasai SPSS. Penerbit Andi, Yogyakarta. $170 \mathrm{hlm}$

Sugiyono. 2010. Metode Penelitian Pendidikan Pendekatan Kuantitatif, Kualitatif dan R\&D. Bandung: Alfabeta.

Supono. 2008. Analisis Diatom Epipelic Sebagai Indikator Kualitas Lingkungan Tambak Untuk Budidaya Udang. Program Studi Magister Manajemen Sumberdaya Pantai, Program Pascasarjana Universitas Diponegoro. Semarang

Tataming E. S., T.K. Sendow, O.H. Kaseke, dan S. Diantje. 2014. Analisis Besar Kontribusi Hambatan Samping Terhadap Kecepatan dengan Menggunakan Model Regresi Linier Berganda (Studi Kasus:Ruas Jalan Dalam Kota Segmen Ruas Jalan Sarapung). Jurnal Sipil Statik. 2(1): 31-32.

Taufik, Muhammad. 2012. Distribusi dan Kelimpahan Larva Ikan di Perairan Laguna Pulau Pari dan Sekitarnya. Program Pascasarjana Institut Pertanian Bogor.

Wibowo. 2010. Arus Laut. Pusat Riset Wilayah Laut dan Sumberdaya Non-Hayati, Jakarta. 